Sección Historia del Derecho Público 

Revista de Estudios Histórico-Jurídicos

[Sección historia del derecho público]

XL (Valparaíso, Chile, 2018)

[pp. 125 - 140]

\title{
The Development of universal Human Rights Law: LATIN AMERICAN COLLABORATION AS KEY DETERMINANTS TO THE INTERNATIONAL HISTORICAL LEGAL PROCESS
}

[El desarrollo de los Derechos Humanos: Colaboraciones Latinoamericanas como factores clave en el proceso legal histórico internacional]

\author{
Paulette BAERISWyl BANCIELlA* \\ Universidad de Zúrich, Suiza
}

\begin{abstract}
RESUMEN
La historia más conocida sobre la creación del sistema universal de derechos humanos establecido después de la Segunda Guerra Mundial por Naciones Unidas, pone énfasis únicamente a las obras de juristas provenientes de Europa, omitiendo el contundente aporte de Latinoamérica. Este trabajo pretende visibilizar la interacción y contribución del continente americano en la consolidación del sistema universal de derechos humanos vigente. La independencia de América se identifica como uno de los factores gatillantes, favoreciendo el desarrollo regional de doctrinas y principios de derecho internacional. Una segunda etapa está conformada por la diseminación del derecho internacional Latinoamericano,
\end{abstract}

\begin{abstract}
The most well-known historical perspective regarding the preparation of the universal system of human rights established after the Second World War by the United Nations only focuses on the work by European lawyers and disregards the important contribution of Latin America. The purpose of this work is to identify the interaction and contribution made by the American Continent regarding the current universal system of human rights. One of the triggering factors was the independence of America, which influenced the regional development of doctrines and principles of the international law. A second stage is the spreading of the international Latin American Law which began with The Hague Peace Conference,
\end{abstract}

RECiBiDo el 30 de abril de 2018 y ACEPTADO el 16 de julio de 2018

* Licenciada en Ciencias Jurídicas de la Pontificia Universidad Católica de Valparaíso, Chile. Abogada, Máster en Derecho y candidata a Doctora en Derecho de la Universidad de Zúrich, Suiza. Dirección postal: Freudenbergstrasse 146, 8044 Zúrich, Suiza. Correo electrónico: paulettebaeriswyl@gmail.com 
que se inicia en las Conferencias de Paz de La Haya, las que por primera vez brindaron tribuna a publicistas provenientes de países no europeos, para intervenir en la gestación de normas vinculantes de derecho internacional. Finalmente se hace mención al trabajo del Instituto Americano de Derecho Internacional, cofundado por el chileno Alejandro Álvarez, cuyas publicaciones influyeron concretamente en la Declaración Americana sobre los Derechos y Deberes del Hombre, la que a su vez sirvió de fuente para la Declaración Universal de Derechos Humanos de Naciones Unidas.

\section{Palabras Clave}

Derecho internacional público Derecho universal de los derechos humanos - Derecho internacional latinoamericano - Principio de no intervención - Principio de la igualdad jurídica - Principio de soberanía de los Estados - Doctrina Drago - Codificación del derecho internacional - Alejandro Álvarez - Conferencias Internacionales de los Estados Americanos. which, for the first time, allowed the participation of publicists from nonEuropean countries to participate in the creation of binding rules of international law. Finally, we mention the work by the American Institute of International Law, co-founded by Chilean Alejandro Álvarez, whose publications directly influenced the American Declaration on the Rights and Duties of Man, which in turn was used as a source for the United Nations Universal Declaration of Human Rights.

\section{KEYWORDS}

International public law - universal human rights law-American international law - principle of non-intervention principle of juridical equality - principle of sovereignty of states - Drago doctrine codification of international law-Alejandro Álvarez - International Conferences of American States.

\section{INTRODUCTION}

How were Latin American ideas about international law and human rights able to penetrate the jurist elite that dominated international law-maker power? The answer can be found in the analyses of the historical legal process, through which Latin American international law doctrines are a trigger element in the creation of our universal system of human rights. The independence of Latin American countries acts as an important factor to the development of Law in the region. Furthermore, the associations of Latin American states at the beginning of the $19^{\text {th }}$ Century gave place to the construction of rules, to create an original school of international law. Another factor is The Hague Peace Conferences, which permitted for the first time the possibility of publicists, come from outside Europe, disseminate their theories to an international audience. The last aspect examined in this work, is the establishment of scientific law societies in the Americas region, in particular the American Institute of International Law, hereafter the American Institute. The American Institute given two influential documents regarding the guarantee of individual rights: The Declaration of the Rights and Duties of Nation of 1916, and the draft on International Rights and Duties of the Individual of 1945. It important to highlight that the American 
Declaration of Rights and Duties of Man, preceded and inspired the creation of a new universal system of international human rights law.

The popular, short and incomplete history of the creation of universal human rights law, are typically associated with the United States President Franklin D. Roosevelt's 1941 State of the Union address, which mentioned the four famous freedoms: of speech, to worship, from want and from fear. Furthermore, the Atlantic Charter of 1941, the Lauterpacht International Bill of Rights of Man of 1945 , inter alia ${ }^{1}$. Also appears to have arisen through the codification of the International Bill of Rights, integrate of the United Nation Universal Declaration of Human Rights of 1948, both of 1966 the International Covenants on Civil and Political Rights, and on Social, Economic and Cultural Rights. It should be noted that equally important international statements come from the American continent, with their significance in the codification of the International Bill of Rights thus far unnoticed. It is this situation that this paper seeks to remedy.

In order to comprehensively understand contemporaneous human rights law, it is necessary to focus on a historical analysis of the Latin American postulates of international law from its basics, namely, the principles of non-intervention and juridical equality of States. International human rights law, as an independent discipline, emerged in the 20th Century from Public International Law, with its own principles constantly in evolution. In addition, the importance of considering the understated contribution of Latin America to the evolution of international law and human rights law, lies within the legitimate recognition of a universal system of human rights. In short, today's universal international human rights law is without a doubt, a result in part of the historical exchange of ideas between Latin America and Europe.

\section{The Independence of Latin America as an}

IMPORTANT FACTOR FOR THE CREATION OF NEW DOCTRINES

OF INTERNATIONAL LAW AND HUMAN RIGHTS

The French Revolution and the Declaration of the Rights of Man and Citizen appear towards the end of the $18^{\text {th }}$ Century, as a historical success with universal repercussion. Also influences on major significance appear the Declaration of Independence of the United States. All these statements inspired liberal ideas of popular sovereignty, which shaping the contours of the modern world, and bringing to the fore the theoretical background for Latin American independence ${ }^{2}$.

In the 19th Century important events related to the proliferation of association or unions at an international level, including governments, prepared the scenario for a new International Era in law. The peace-seeking movements emerged from different parts of the world, requesting disarmament, alternatives to war, and peaceful settlement or arbitration. With the Congress of Vienna of 1815, arose

${ }^{1}$ Bates, Ed, History, in Moeckli, Daniel et al., International Human Rights Law (2 $2^{\text {nd }}$ edition, Oxford, 2014), p. 15.

2 WallersteIn, Immanuel, The Modern World-System IV, Centrist Liberalism Triumphant, 1789-1914, (California, 2011), pp. $22 \mathrm{ff}$. 
in Europe the idea of regular meetings in the form of conferences or congresses between states. The concert system constituted a significant development to achieve peace in international relations. It was recognised the need to institutionalize regular multilateral negotiations, as an alliance engaging in diplomacy according to ethical standards. The congresses following 1815, and during the 19th Century, were originally regional in scope. Nevertheless, the congresses idea evolved eventually into ones with an international dimension, giving origin to international organisations ${ }^{3}$.

At that time, International law still legitimated colonial exploitation and developed mechanisms to prevent colonial reparations. European States did not consider non-European States to be sovereign as well. The European old model of sovereignty, established since the Peace of Westphalia of 1648, stay unalterable, assigning a different concept of sovereignty to non-European countries, rendering them uniquely vulnerable and dependent on international law ${ }^{4}$.

Simón Bolívar (1793-1830), a liberal Venezuelan political, which supported the emancipation of various Latin American countries, was precursory of the idea to create a confederation of Latin Americas States, influenced by the Congress of Vienna, in the American continent. Thus, in 1826 took place the Congress of Panama, which was organized by Bolivar ${ }^{5}$. Latin American States decided to organize themselves, encountering common external threats from European Powers. By the end of the 19th Century, the series of conferences that followed encouraged a notion of union between the American countries ${ }^{6}$. The Congress of Panama gave expression to ideas of cooperation and regional solidarity, originating in the fear of losing the freshly gained independence of the continent from Spain and Portugal. This scenario allowed the development of a Latin American international law, as a set of doctrines and principles by diplomats and jurists of the created countries, nourished from classical European ideas and postulates.

\section{The effects of The Hague Peace Conferences of 1899 and 1907 on Latin American Countries}

The Hague Peace Conferences signified the beginning of Latin American interaction regarding international law. From the commencement of the 19th Century, peace movements began to push the codification of international law.

${ }^{3}$ SAnDS, Philippe; KLeIN, Pierre, Bowett's Law of International Institutions $\left(6^{\text {th }}\right.$ edition, United Kingdom, 2009), pp. $3 \mathrm{ff}$.

${ }^{4}$ ANGHIE, Antony, Imperialism, Sovereignty and the Making of International Law (United Kingdom, 2008), pp. 2-6.

5 Shelton, Dinah L.; Carozza, Paolo G, Regional Protection of Human Rights ( $2^{\text {nd }}$ edition, Oxford, 2013), p. 53; WallersteIn, Immanuel, The Modern World-System III, The Second Era of Great Expansion of the Capitalist World-Economy 1730-1840, (California, 2011), p. 254.

${ }^{6}$ See Horwitz, Betty; Bagley, Bruce, Latin America and the Caribbean in the Global Context, Why care about the Americas? (New York, 2016), p. 182; Shelton, Dinah L.; Carozza, Paolo G, cit. (n. 5), p. 11. 
The impact of these worldwide coalitions was fundamental, to the realization of the Peace Conferences ${ }^{7}$.

The First Hague Peace Conference of 1899 represented the first major multilateral international conference gathering, indicating the start of an International $\mathrm{Era}^{8}$. The aim was to prevent war, and although most countries were European, participation did include states such as Turkey. Asia was represented by Persia, Siam, China and Japan, the Americas by the United States and Mexico. Africa was not represented'. The achievements of the First Hague Peace Conference were three Conventions and three Declarations ${ }^{10}$. The establishment of the Permanent Court of Arbitration on 19 September 1900, still in existence, was the result of the Convention on the Pacific Settlement of International Disputes. Although the objective of an obligatory international jurisdiction was not obtained, the Permanent Court of Arbitration did serve as a first step to attain an international tribunal, with general jurisdiction ${ }^{11}$. However, the real innovation of the First Hague Peace Conference was in establishing a template for multilateral international conferences based on the principle of equality of states, with the effects of this outside Europe, sowing the seeds for universal international law ${ }^{12}$.

Although Mexico, was the only state from Latin American represented at the First Hague Peace Conference, the repercussions of this conclave gave impulse to the strengthening of the regional movement in the American continent, initiated with Simón Bolivar in Congress of Panama of 1826. The President of the United States of America, with the support of the Senate and House of Representatives, invited States of the American Continent to Washington DC., to join in the creation of the Union of American Republic ${ }^{13}$, in the First International Confe-

${ }^{7}$ LYNCH, Cecelia, Peace Movements, Civil Society, and the Development of International Law, in Fassbender, Bardo; Peters, Anne et. al., The Oxford handbook of the History of International Law (Oxford, 2012), pp. 198-210.

${ }^{8}$ Eyffinger, Arthur, The 1899 Hague Peace Conference, The Parliament of Man, the Federation of the World (Netherlands, 1999), p. 2; See Rosenne, Shabtai, The Permanent Court of Arbitration, The Hague Peace Conferences of 1899 and 1907 and International Arbitration, Reports and Documents (The Hague, 2001), p. xvii.

${ }^{9}$ Joon, Johan, The way of Law above the way of violence, The history of the Peace Palace and its working bodies, particularly the Permanent Court of Arbitration, the International Court of Justice, The Hague Academy of International Law, the Carnegie Foundation and the Library, 1913-2013, in Carnegie Foundation (ed.), The Building of Peace, A Hundred Years of Work on Peace Through Law: The Peace Palace 1913-2013 (The Hague, 2013), p. 26.

10 Convention I on the Pacific Settlement of International Disputes; Convention II respecting the Laws and Customs of War on Land; and Convention III for the adaptation to maritime warfare of the principles of the Geneva Convention of August 22, 1864; Declaration to prohibit the discharge of projectiles and explosives from balloons or by other similar new methods, the Declaration to prohibit the use of projectiles, the only object of which is the diffusion of asphyxiating or deleterious gases, and the Declaration to prohibit the use of bullets which expand or flatten easily in the human body, such as bullets with a hard envelope which does not entirely cover the core or is pierced with incisions; See RosEnNE, Shabtai, cit. (n. 8), pp. xvi, 136.

${ }^{11}$ See Rosenne, Shabtai, cit. (n. 8), pp. xviii ff.

12 Rosenne, Shabtai, cit. (n. 8), p. xvii.

13 The Union of American Republic organization was absorbed by the Pan American Union 
rence of American States of $1889^{14}$. The agenda of the conferences had to discuss topics related for example: to the regulation of the economics relations between the members, and the elaboration of a plan of arbitration for the settlement of disagreements and disputes ${ }^{15}$. The principle of arbitration gains the character of a cornerstone of American international law, as an obligatory measure. Accordingly, the adopted plan of arbitration served as draft for one future treaty of Arbitration for the settlement of disputes between the members, signed in April 28, $1890{ }^{16}$.

Subsequently, in the framework of the Union of American Republic were held a series of conferences, opening up an important forum for Latin American States and the United States ${ }^{17}$. The Second International Conference of American States of 1901, in Mexico, replicated the ideals pursued by the First Hague Peace Conference, and adopted another General Treaty on Arbitration. In the following conferences, the Latin American States continued displaying their interest in the systematization of international law and took their participation to universal level ${ }^{18}$.

Despite the criticism of recognised international lawyers about the inclusion of new states at the Second Hague Peace Conference of 1907, the scenery changed with an increased participation of eighteen Latin American States ${ }^{19}$. This greater presence was due to the drawing up of the Drago Doctrine, which gave way for invitations to be sent to all Latin American States ${ }^{20}$. In preparation for the Second Hague Peace Conference, the Latin American countries organized the Third International Conference of American States in Rio de Janeiro in 1906, with the decision to submit the Drago Doctrine to Europe. The Doctrine highlighted the

created in 1910. See BRown ScotT, James, The International Conferences of American States, 1889-1928 (New York 1931), pp. $172 \mathrm{ff}$.

${ }^{14}$ In July of 1888 was sent the invitation to the conferences submitted by the President to United States, and the First Conference was held in 1889. The United States took the chair, and participated also Argentina, Bolivia, Brazil, Chile, Colombia, Costa Rica, Ecuador, Guatemala, Haiti, Honduras, Mexico, Nicaragua, Paraguay, Peru, El Salvador, United States of America, Uruguay and Venezuela. See Brown SCOTT, James, The International Conferences of American States, 1889-1928, cit. (n. 13), pp. 9 ff.

${ }^{15}$ Act of Congress of 1May 24, 1888, authorizing the President of the United States to arrange a conference between the United States of America and the Republics of Mexico, Central and South America, Haiti, San Domingo, and the Empire of Brazil; See Brown ScotT, James, The International Conferences of American States, 1889-1928, cit. (n. 13), pp. $3 \mathrm{ff}$.

${ }^{16}$ Plan of Arbitration, Article I and II; See Brown ScotT, James, The International Conferences of American States, 1889-1928, cit. (n. 13), pp. 40 ff.

17 BeCKer LorCA, Arnulf, Human Rights in International Law? The Forgotten Origins of Human Rights in Latin America, in University of Toronto Law Journal, 4/67 (2017), p. 478.

${ }^{18}$ Cançado Trindade, Antonio, The Contribution of Latin American Legal Doctrine to the Progressive Development of International Law, in Recueil des cours, 376 (2014), pp. 25 f.; AreLLANO, Juan C., La Doctrina Drago y Su Importancia Americanista, in Conference pronounced in the Mitre Museum of Buenos Aires, 24 October 1976, p. 157.

${ }^{19}$ For example, the English law scholar John Westlake, see BeCKer LoRCA, Arnulf, cit. (n. 17), p. 30.

${ }^{20}$ Cançado Trindade, Antonio, The Contribution of Latin American Legal Doctrine to the Progressive Development of International Law, cit. (n. 20), pp. 26 ff.; Arellano, Juan C., cit. (n. 18). 
principle of the prohibition of the use of force or coercion in inter-State relations, regarding the recovery of public debts ${ }^{21}$.

The Doctrine was created by an Argentine jurist, Luis María Drago (18591921). He as Minister of Foreign Affairs, was sent to Washington in 1902, to protest against the armed attack because the recovery of a public debt by Germany, Great Britain and Italy on Puerto Cabello, Venezuela. The diplomatic note recalled the principles of juridical equality and sovereignty of States, and declared that the Republic of Argentina wished that all world powers would respect the principle, which prohibited the armed intervention and territorial occupation in order to collect public debts ${ }^{22}$. Indeed, Luis María Drago joined to the Second Hague Peace Conference as a delegate of Argentina, and together with the delegates of other Latin American States, promoted said principle ${ }^{23}$.

The result of the Second Hague Peace Conference, was the adoption of thirteen Conventions, including the Convention on Limitation of Force for the Recovery of Ordinary Public Debts, the so-called Drago-Porter Convention, which draws on the Drago Doctrine ${ }^{24}$. The Conventions created a powerful set of rules related to the conduct of wars and conflict resolution ${ }^{25}$. Furthermore, the restatement of the principle of juridical equality of States, represented a significant progress in the development of international law.

Although the Second Hague Peace Conference constituted a feature in the codification and evolution of international law, it failed nonetheless, to achieve the creation of a permanent tribunal for international arbitration, as was as the will of the Latin American delegations ${ }^{26}$. The Acte final of the Conference consigned the expressed wish for the creation of an Arbitral Court of Justice, and the ideal of compulsory international arbitration ${ }^{27}$.

In keeping with this desire of a compulsory permanent jurisdiction, the Central American States, created the Central American Court of Justice in 1907, with a limited scope for the five convened States ${ }^{28}$. The Court's jurisdiction covered inter-State disputes, as well disputes of individuals against States Parties. Acting on several human rights matters, the Court transformed into the first human

${ }^{21}$ Fabella, Isidro, Intervention, (Paris, 1961), pp. 144-145.

22 Arellano, Juan C., cit. (n. 18), pp. 156 ff.

23 Cançado Trindade, Antonio, The Contribution of Latin American Legal Doctrine to the Progressive Development of International Law, cit. (n. 20), pp. 26 ff.; Arellano, Juan C., cit. (n. 18).

${ }^{24}$ Cançado Trindade, Antonio, The Contribution of Latin American Legal Doctrine to the Progressive Development of International Law, cit. (n. 20), pp. 29, 42-43, 46.

25 Annemhuis, Maartje; Barber, Christopher; Higgins, Annalise (editors), War, Peace and International Order? The Legacies of the Hague Conferences of 1899 and 1907 (Great Britain, 2017), p. 3.

${ }^{26}$ Cançado Trindade, Antonio, The Contribution of Latin American Legal Doctrine to the Progressive Development of International Law, cit. (n. 20), pp. 29, 42-43, 46.

${ }^{27}$ Ibíd., pp. 32, 51. See Rosenne, Shabtai, cit. (n. 8), pp. xxii ff.

${ }^{28}$ Costa Rica, El Salvador, Guatemala, Honduras and Nicaragua. CANÇADO Trindade, Antonio, The Contribution of Latin American Legal Doctrine to the Progressive Development of International Law, cit. (n. 20), p. 59. 
rights tribunal in the world ${ }^{29}$. Although the Central American Court of Justice operated only ten years, its work contributed to laying the foundations of the ideal of international justice ${ }^{30}$. In the rest of the World before the First World War, sovereign States were not pressured into ensuring guarantees and protection of individuals' rights ${ }^{31}$.

In short, The Hague Peace Conferences sparked an International Era in the development of international law, opening New World jurists to the possibility of creating innovative principles and developing theories, achieving more justice in the interaction with the Old World. Even though a third Hague Peace Conference was planned, it never took place, due to the onset of the First World War ${ }^{32}$.

If the peace movements in the 19th Century were principally theoretical, in the 20th Century they were translated into action with concrete results: the establishment of the Permanent Court of Arbitration, the Permanent Court of International Justice, the creation of the League of Nation, and culminating in the establishment of the United Nations ${ }^{33}$.

\section{LAW SOCIETIES IN THE AMERICAS: THE AMERICAN INSTITUTE OF INTERNATIONAL LAW}

The American Institute was an international scientific association ${ }^{34}$, cofounded in 1912, by the Chilean jurist Alejandro Álvarez (1868-1960), with the most prestigious U.S. internationalist of the time, James Brown Scott (1866-1943) together ${ }^{35}$. The financial support came from the Carnegie Endowment for Peace, and the auspice of the Second Pan American Scientific Congress to develop international law in the Americas, and determine standards of rights, among the twenty-one participating American Republics ${ }^{36}$. Thereby, the Institute's aim focused on international law, as the codification of international law, the promotion of the principle of non-intervention, and the protection of individual liberties, taking into account the special circumstances of the region's countries ${ }^{37}$.

29 Shelton, Dinah L., Advanced Introduction to International Human Rights Law (Great Britain, 2014), p. 38.

30 Cançado Trindade, Antonio, Los Aportes Latinoamericanos al Derecho y a la Justicia Internacionales, in CANÇADO TRINDADE, Antonio et al., Doctrina Latinoamericana del Derecho Internacional, I: Corte Interamericana de Derechos Humanos (Costa Rica, 2003), pp. 49, 60.

31 Bates, Ed, cit. (n. 1), pp. 27 ff.

32 Annemhuis, Maartje; Barber, Christopher; Higgins, Annalise (editors), cit. (n. 25), p. 4.

33 LYNCH, Cecelia, cit. (n. 7).

34 The expression "American" in this context refers to the American Continent as a whole, and not only the United States, as has been inaccurately used.

35 BeCKer LorCA, Arnulf, Mestizo International Law, a Global Intellectual History 1842-133 (United Kingdom, 2014), p. 328.

36 BRown SCOTT, James, The American Institute of International Law: In Declaration of the Rights and Duties of Nations (Washington, 1916), p. 2.

${ }^{37}$ Root, Elihu, The Declaration of the Rights and Duties of Nations Adopted by the American Institute of International Law, in The American Journal of International Law, 2/10 (1916), p. 212; OBREgón, Liliana, The Universal Declaration of Human Rights in Latin America, in Maryland 
The contribution of the American Institute was considered "the most influential non-official efforts" to the International Bill of Rights ${ }^{38}$.

The inclusion of the United States in the Institute, with Brown Scott, had the purpose of avoiding division between North American and Latin American $S_{\text {tates }}{ }^{39}$. If Álvarez believed in a unified universal international law future, he also supported an original stream of international law, called in his words: "American International Law". The American international law embraced the solidarity principle, predominantly due to similarities experienced regarding revolution and independence processes ${ }^{40}$. Álvarez believed also, that the reconstruction of international law could come from the Pan American Union, founded in 1910, by the Fourth International Conference of American States, in Buenos Aires. The Pan American Union replaces the old "Union of American Republic", reorganizing them as a permanent organisation with several organs, functioning in regular monthly sessions, with seat in Washington $\mathrm{DC}^{41}$. At the Fourth International Conference of American States, in Buenos Aires, Alejandro Álvarez participated as technical delegate, representing Chile ${ }^{42}$.

In 1948 the Pan American Union was replaced by the Organization of American States still working in DC.

The Latin American School of thought focused on the study of a body of laws of universal character, governed by solidarity, contrasting with the Anglo-Saxon School, of thought which examined a body of laws with exclusive and narrow national interests ${ }^{43}$. The idea of having a universal unified law represented a threat, to the established monopoly of international law-maker power. European internationalists were reluctant at the possibility of competition in the creation of international law rules. One example is the Belgian Professor and Judge Edmond Picard, who adduced the idea of a universal uniform law as a utopia, basing his position on racial differences between the nations of the World ${ }^{44}$. In contrast, the American Institute contributed with two early statements, recognising individual human rights, which were important instruments, used in drafts for regional conventions, also in the post-World War II international human rights project. The

Journal of International Law, 94/24 (2009), p. 95; KECK, Margaret; SIKKINK, Kathryn, Activist Beyond Borders (United States of America, 1998), pp. $84 \mathrm{ff}$.

${ }^{38}$ SChabas, William, The Universal Declaration of Human Rights, The Travaux Préparatoires (Cambridge, 2013), I, p. lxxiii.

39 OBRegón, Liliana, cit. (n. 37).

${ }^{40}$ ÁlvareZ, Alejandro, Chapter V, The Influence of the Napoleonic Codification in the other Countries, in Various Authors, The Progress of Continental law in the Nineteenth Century (Boston, 1918), p. 261 (footnote).

${ }^{41}$ Brown SCotT, James, The International Conferences of American States, 1889-1928, cit. (n. 13), pp. 9 ff.

${ }^{42}$ Ibid., pp. $162 \mathrm{ff}$.

${ }_{43}$ ÁlvareZ, Alejandro, International Law and related Subjects from the Point of View of the American Continent, A Report on Lectures delivered in the Universities of the United States, 19161918 (Washington, 1922), pp. 13 ff., 37.

${ }^{44}$ PICARD, Edmond, Chapter XIV, A World Common Law: Its Need, Its Scope, and Its Prospects, A Symposium, The Necessary Diversity of Law, According to Races and Nations, in Various AutHors, The Progress of Continental law in the Nineteenth Century (Boston, 1918), pp. 520-522. 
solidarity idea from the Pan-American Union since 1890, gave a new approach to the international law of the 19th and 20th Century, seeking more equality and justice in relations between States.

\section{The Declaration of the Rights and Duties of Nations}

The American Institute, at its first session in 1916, adopted the Declaration of the Rights and Duties of Nations, as a statement of principles of the American international law. In fact, this declaration consecrates the principle of nonintervention, juridical equality, sovereignty of States, and others, collected by the doctrines of Andrés Bello, Carlos Calvo and principles of Anglo-American $\mathrm{Law}^{45}$. This manifesto represents an attempt at international unification and universalization of law, an idea strongly promoted by Álvarez, and supported by Brown $\mathrm{Scott}^{46}$. Álvarez tried to reshape the principles of international law governing the 19th Century, which had permitted imperialism, to move onto concepts that allowed the new countries a just development, founded on the ideas of the Venezuelan Andrés Bello and the Argentinian Carlos Calvo. He saw a future international law as a universal rule under which international relations fostered good relations between states, under a spirit of solidarity to ensure peace, overcoming the different schools of thought, to fulfil the maxim "Above all nations is humanity" ${ }^{47}$. Nevertheless, European international lawyers still tend to downplay Latin American international law ideas, referring to them as deviations ${ }^{48}$. This rejection by western international lawyers prolongs the idea of an exclusive European international law, and the exclusion of non-European states from the privileges of sovereign equality ${ }^{49}$.

The Declaration of the Rights and Duties of Nations recognised, for the first time, in its preamble individuals' human rights, namely the right to life, liberty, pursuit of happiness, equality before the law, property and the right to the observance thereof, as fundamental rights collected by national jurispruden$\mathrm{ces}^{50}$. The included international rights of the individual should be recognised for all individuals living in countries in the Americas, regardless of nationality. Nevertheless, the statement was only oriented to the rights and duties of nations in relation to other nations, being the first document to promote the rights of man, in a purely international context. At the Seventh International Conference of American States of 1933, in Montevideo, the Declaration of the Right and

45 Brown ScotT, James, The American Institute of International Law: In Declaration of the Rights and Duties of Nations, cit. (n. 36), pp. forewords, 88-101.

46 Obregón, Liliana, cit. (n. 37); Álvarez, Alejandro, Chapter V, The Influence of the Napoleonic Codification in the other Countries, cit. (n. 40), pp. 261-262.

${ }^{4}$ Álvarez, Alejandro, International Law and related Subjects from the Point of View of the American Continent, cit. (n. 43), pp. 37-38.

48 BeCKer LorCA, Arnulf, Mestizo International Law, a Global Intellectual History 18421933, cit. (n. 35), p. 30.

49 Anghie, Antony, cit. (n. 4), p. 46.

${ }^{50}$ Brown ScotT, James, The American Institute of International Law: In Declaration of the Rights and Duties of Nations, cit. (n. 36), p. 87. 
Duties of Nations became the Convention on the Rights and Duties of States ${ }^{51}$. Later, the United Nation General Assembly in 1949, used the content of the Declaration of the Rights and Duties of Nations, to prepare the Draft Declaration on Rights and Duties of States in the form of a resolution ${ }^{52}$.

\section{The draft International Rights and Duties of the Individual by Álvarez and} the American Declaration of the Rights and Duties of Man

The Declaration of the Rights and Duties of Nations served as starting point to the draft International Rights and Duties of the Individual submitted by Álvarez in 1945, to the Fourth Inter-American Lawyers Conference, in Santiago de Chile $^{53}$. The American Declaration of the Rights and Duties of Man, based on Álvarez's initial draft, was adopted in 1948 between March 30 and May 2, at the Ninth International Conference of American States, in Bogotá. The Charter of the Organization of American States was also adopted, creating the organization, which succeeded the Pan-American Union ${ }^{54}$. The aim of the Organization of American States members behind the American Declaration, was to guarantee a minimum standard of civilized justice equally, applicable to all nationals and foreigners residing in Latin American territory.

The American Declaration was the first international instrument, albeit with regional scope, that recognised human rights, codifying ideas emerging from the American Continent, and dating back to the beginning of the 19th Century. Nevertheless, it is arguable that its underlying aim was related to preventing intervention in Latin American countries, by major powers from outside the region. In this scenario, the purpose was to secure a homogeneous catalogue of guarantees recognised by all Members States, and ensure a minimum standard of justice, thus allowing the fully validity of the principle of juridical equality of states.

In that time, the diplomatic protection figured as a common form to be involved in domestic matters of the new countries. With this proposal in mind, the American Declaration was an attempt to avoid external intervention in the region, using the excuse of diplomatic protection, securing a minimal standard of rights to all citizens. This idea was combined with the Latin American purpose of strengthening the principles of juridical equality of States, and of non-intervention ${ }^{55}$.

In 1942, Hersch Lauterpacht was working on the elaboration of the International Bill of the Rights of Man, at the invitation of the American Jewish Committee. Lauterpacht given lectures as Professor of international law, at Cambridge University, and he had been a disciple to Kelsen in Vienna, when Kelsen was

${ }^{51}$ Convention on Rights and Duties of States, of 26 December 1933.

52 A/RES/375 (IV), of 6 December 1949.

${ }^{53}$ Obregón, Liliana, cit. (n. 37), pp. $95 \mathrm{ff}$.

${ }^{54}$ The Member States of the Organization of American States are: Antigua and Barbuda, Argentina, Bahamas, Barbados, Belize, Bolivia, Brazil, Canada, Chile, Colombia, Costa Rica, Cuba, Dominica, Dominican Republic, Ecuador, El Salvador, Grenada, Guatemala, Guyana, Haiti, Honduras, Jamaica, Mexico, Nicaragua, Panama, Paraguay, Peru, Saint Kitts and Nevis, Saint Lucia, Saint Vincent and the Grenadines, Suriname, Trinidad and Tobago, United States, Uruguay, and Venezuela.

55 OBREGÓn, Liliana, cit. (n. 37), p. 96. 
working on the Austrian constitution. Nevertheless, when Lauterpacht started to work on the Bill, the American Institute and Alejandro Álvarez had already examined individual rights under international law ${ }^{56}$. In the European version of history on the universalization of the human rights, the 1945 International Bill of the Rights of Man written by Hersch Lauterpacht is considered as the main source of inspiration of the Universal Declaration and also for the 1950 European Convention on Human Rights ${ }^{57}$. However, the draft International Rights and Duties of the Individual by Álvarez, the American Declaration of the Rights and Duties of Man, and the work of the American Law Institute have not been made visible, as an important source. This less popularity is in despite of the fact, that the final draft of the American Declaration was used in the elaboration of the United Nations Universal Declaration of Human Rights, eight months later, which was adopted and proclaimed on December 10, 1948 by the General Assembly ${ }^{58}$.

One can observe in a textual example, how the American Declaration inspired the content of article 8 of the Universal Declaration of Human Rights, about the right to an effective remedy, which are repeated in article 13 of the European Convention of Human Rights:

Article 8 of the Universal Declaration of Human Rights: "Everyone has the right to an effective remedy by the competent national tribunals for acts violating the fundamental rights granted him by the constitution or by law".

Article XVIII of the American Declaration of the Rights and Duties of Man: "Every person may resort to the courts to ensure respect for his legal rights. There should likewise be available to him a simple, brief procedure whereby the courts will protect him from acts of authority that, to his prejudice, violate any fundamental constitutional rights".

Article 13 of the European Convention of Human Rights: "Everyone whose rights and freedoms as set forth in this Convention are violated shall have an effective remedy before a national authority notwithstanding that the violation has been committed by persons acting in an official capacity" 59 .

The right to access an effective remedy is now one of the basic pillars of the rule of law in a democratic society ${ }^{60}$. As an example of his considerable importance, the $15,5 \%$ of judgments delivered by European Court of Human Rights in 2017, were referred to this violation, constituting this right, the third most violated ${ }^{61}$.

56 SANDS, Philippe, Introduction of the book an International Bill of the Rights of Man, in LAUTERPACHT, Hersch, An International Bill of the Rights of Man (2 ${ }^{\text {nd }}$ edition, New York, 2014), pp. vii ff.

57 See Bates, Ed, cit. (n. 1), p. 15.

58 Obregón, Liliana, cit. (n. 37), p. 96; Shelton, Dinah L., cit. (n. 29), pp. 38-39; A/ RES/217 (III) of 10 December 1948.

59 Cançado Trindade, Antonio, The Contribution of Latin American Legal Doctrine to the Progressive Development of International Law, cit. (n. 20), p. 78.

${ }^{60}$ Cançado Trindade, Antonio, Los Aportes Latinoamericanos al Derecho y a la Justicia Internacionales, CIT. (N. 30), P. 60.

${ }^{61}$ European Court of Human Rights, Statistic by year 2017, violations by article and by state 2017 [available at: <http://echr.coe.int/Pages/home.aspx?p=reports\&c=\#n1347956867932_ pointer> (last visited: 23 April 2018)]. 
In the drafting of the United Nations Charter, signed in San Francisco on 26 June 1945, the Latin American States together with non-governmental organizations insisted, without success, on the inclusion of human rights provisions ${ }^{62}$. Although there was no initial triumph, in the year following, 1948, they achieved their purpose with the Universal Declaration of Human Rights ${ }^{63}$. The Latin American States were able to seriously engage at the United Nation Conference in San Francisco, having learned the importance of acting as a regional bloc at the Second Hague Peace Conference, where they achieved enormous influences in the final resolutions ${ }^{64}$. The anticipated preparation by the Latin American countries for the international conferences, proved rich results for the region, and strengthened its quest for the development of the codification of international law and human rights.

The idea of codifying international law in the American Continent, can be traced back to Simón Bolivar, and his desire for continental unity expressed at the Congress of Panama in 1826, resurging with the Pan-American Union until 1889, influenced by Alejandro Álvarez, and again, under the assistance of the American Institute, and the Organization of American States ${ }^{65}$.

\section{CONCLUSION}

The Latin American contribution to the corpus juris of the international law of human rights is undeniable ${ }^{66}$. The American Declaration of the Rights and Duties of Man appeared, as the first international statement, and legal instrument of human rights ${ }^{67}$. Despite the evolution of international law in Latin America being defensive measures in response to external threats, this unique situation has turned the region into a world leader in this field ${ }^{68}$. The independence of the Latin American Countries allowed the creation of a regional system in the Americas, which had been contributing in the progress of the international law, and human rights law.

Meanwhile, in Europe, the Second World War, the Nazi regime, and the atrocities committed during the Holocaust, shook the region into promoting the idea of human rights as an international norm, and limiting state sovereignty,

${ }^{62}$ Shelton, Dinah L., cit. (n. 29), p. 32; Glendon, Mary Ann, The Forgotten Crucible: The Latin American Influence on the Universal Human Rights Idea, in Harvard Human Rights Journal, 16 (2003), p. 27.

${ }^{63}$ Schabas, William A., cit. (n. 38), p. lxxvii; Glendon, Mary Ann, cit. (n. 62).

${ }^{64}$ OBRegón, Liliana, cit. (n. 37), p. 96.

${ }^{65}$ BeCKer LorCA, Arnulf, Mestizo International Law, a Global Intellectual History 18421933, cit. (n. 35), p. 327.

${ }^{66}$ Cançado Trindade, Antonio, The Contribution of Latin American Legal Doctrine to the Progressive Development of International Law, cit. (n. 20), p. 20.

${ }_{67}$ BeCKer LorCa, Arnulf, Human Rights in International Law? The Forgotten Origins of Human Rights in Latin America, cit. (n. 17), p. 476.

${ }^{68}$ Horwitz, Betty; Bagley, Bruce, cit. (n. 6), p. 182. See Hillebrecht, Courtney, Domestic Politics and International Human Rights Tribunals, The Problem of Compliance $\left(2^{\text {nd }}\right.$ edition, United Kingdom, 2013), p. 8. 
propelling the necessity for an international declaration that incorporated the protection of the fundamental rights of man, as an integral part of the world order ${ }^{69}$. In the other side, in the Americas, the ideas of unity, solidarity, codification of international law rules, and the recognition of individual guarantees, had already started in the 19th Century.

It is therefore possible to appreciate also, that the development of universal international law, derived from a clear exchange of principles and doctrines predominantly, between Europe and Latin America. Particularly, in the New World, theirs was a reaction of fending off foreign policies of expansion and intervention by the major powers, best illustrated by the realisation and achievements of The Hague Peace Conferences, Congress of Panama and International Conferences of American States.

Human Rights gained international legitimacy for first time in the 20th Century, and the importance of the Universal Declaration at the time of its creation was only a "common standard of achievement". Today it is an accepted source of customary international law ${ }^{70}$. The Universal Declaration is considered to be an authoritative interpretation of the United Nations Charter, and together has shaped the constitutional structure of the world community, ensuring the codification of human rights ${ }^{71}$.

\section{BIBLIOGRAPHY}

\section{Monographies}

ÁLVAREZ, Alejandro, International Law and related Subjects from the Point of View of the American Continent, A Report on Lectures delivered in the Universities of the United States, 1916-1918, (Washington, 1922).

ANGHIE, Antony, Imperialism, Sovereignty and the Making of International Law (United Kingdom, 2008).

Arellano, Juan C., La Doctrina Drago y Su Importancia Americanista, in Conference pronounced in the Mitre Museum of Buenos Aires, 24 October 1976 [available at: <http://acienpol.msinfo.info/bases/biblo/texto/boletin/1977/Bo1ACPS_1977_36_71_151-157.pdf> (last visited: 24 February 2018)].

BeCKer LorCA, Arnulf, Mestizo International Law, a Global Intellectual History 18421933 (United Kingdom, 2014).

Brown ScotT, James, The American Institute of International Law: In Declaration of the Rights and Duties of Nations (Washington, 1916).

BRown SCOTT, James, The International Conferences of American States, 1889-1928 (New York 1931).

69 Callaway, Rhonda; Harrelson-Stephens, Julie, Exploring International Human Rights, Essential reading (United States of America, 2007), p. 1; LAUTERPACHT, Hersch, An International Bill of the Rights of Man, ( $2^{\text {nd }}$ edition, New York, 2014), p. XXVII.

70 Shelton, Dinah L., cit. (n. 25), p. 19; ReISMan, Michael, Sovereignty and Human Rights in Contemporary International Law, in SHELTON, Dinah, International Protection of Human Rights (Netherlands, 2017), p. 382.

71 Shelton, Dinah L.; Carozza, Paolo G, cit. (n. 5), pp. 5-7. 
Eyffinger, Arthur, The 1899 Hague Peace Conference, The Parliament of Man, the Federation of the World (Netherlands, 1999).

FABELLA, Isidro, Intervention (Paris, 1961).

Hillebrecht, Courtney, Domestic Politics and International Human Rights Tribunals, The Problem of Compliance ( $2^{\text {nd }}$ edition, United Kingdom, 2013).

LaUterpacht, Hersch, An International Bill of the Rights of Man ( $2^{\text {nd }}$ edition, New York, 2014).

Rosenne, Shabtai, The Permanent Court of Arbitration, The Hague Peace Conferences of 1899 and 1907 and International Arbitration, Reports and Documents (The Hague, 2001).

Schabas, William A., The Universal Declaration of Human Rights, The Travaux Préparatoires, 1 (Cambridge, 2013).

SHELTON, Dinah L., Advanced Introduction to International Human Rights Law (Great Britain, 2014).

Wallerstein, Immanuel, The Modern World-System III, The Second Era of Great Expansion of the Capitalist World-Economy 1730-1840 (California, 2011).

WaLlersteIn, Immanuel, The Modern World-System IV, Centrist Liberalism Triumphant, 1789-1914 (California, 2011).

\section{EDITED VOLUMES}

ALVAREZ, Alejandro, Chapter V, The Influence of the Napoleonic Codification in the other Countries, in VArious Authors, The Progress of Continental law in the Nineteenth Century (Boston, 1918), pp. 251-262.

Annemhuis, Maartje; Barber, Christopher; Higgins, Annalise (editors), War, Peace and International Order? The Legacies of the Hague Conferences of 1899 and 1907 (Great Britain, 2017).

Bates, Ed, History, in Moeckli, Daniel (et al.), International Human Rights Law (2 ${ }^{\text {nd }}$ edition, Oxford, 2014).

Callaway, Rhonda; Harrelson-STEPHENS, Julie, Exploring International Human Rights, Essential reading (United States of America, 2007).

Cançado Trindade, Antonio, Los Aportes Latinoamericanos al Derecho y a la Justicia Internacionales, in Cançado Trindade, Antonio; Martínez Moreno, Alfredo, Doctrina Latinoamericana del Derecho Internacional, I: Corte Interamericana de Derechos Humanos (Costa Rica, 2003), pp. 33-64 [available at: <https://archivos. juridicas.unam.mx/www/bjv/libros/5/2452/5.pdf> (LAST VISITED: 24 FEBRUARY 2018)].

Horwitz, Betty; Bagley, Bruce, Latin America and the Caribbean in the Global Context, Why care about the Americas? (New York, 2016).

Joor, Johan, The way of Law above the way of violence, The history of the Peace Palace and its working bodies, particularly the Permanent Court of Arbitration, the International Court of Justice, The Hague Academy of International Law, the Carnegie Foundation and the Library, 1913-2013, in CARnEgie Foundation (ed.), The Building of Peace, A Hundred Years of Work on Peace Through Law: The Peace Palace 1913-2013 (The Hague, 2013).

KeCK, Margaret; SikKINK, Kathryn, Activist Beyond Borders (United States of America, 1998).

Lynch, Cecelia, Peace Movements, Civil Society, and the Development of International 
Law, in Fassbender, Bardo; Peters, Anne et. al., The Oxford handbook of the History of International Law (Oxford, 2012).

PiCARD, Edmond, Chapter XIV, A World Common Law: Its Need, Its Scope, and Its Prospects, A Symposium, The Necessary Diversity of Law, According to Races and Nations, in Various Authors, The Progress of Continental law in the Nineteenth Century (Boston, 1918), pp. 520-535.

ReISMAN, Michael, Sovereignty and Human Rights in Contemporary International Law, in SHelton, Dinah, International Protection of Human Rights (Netherlands, 2017), pp. 382-402.

SANDS, Philippe, Introduction of the book an International Bill of the Rights of Man, in LaUTeRPaCHT, Hersch, An International Bill of the Rights of Man ( $2^{\text {nd }}$ edition, New York, 2014).

SANDS, Philippe; KLEIN, Pierre, Bowett's Law of International Institutions, (6 ${ }^{\text {th }}$ edition, United Kingdom, 2009).

Shelton, Dinah L.; Carozza, Paolo G., Regional Protection of Human Rights (2 ${ }^{\text {nd }}$ edition, Oxford, 2013).

\section{ARTICLES IN JOURNALS}

Becker LorCA, Arnulf, Human Rights in International Law? The Forgotten Origins of Human Rights in Latin America, in University of Toronto Law Journal, 4/67 (2017), pp. 465-495.

Cançado Trindade, Antonio, The Contribution of Latin American Legal Doctrine to the Progressive Development of International Law, in Recueil des cours, 376 (2014), pp. 19-92.

Glendon, Mary Ann, The Forgotten Crucible: The Latin American Influence on the Universal Human Rights Idea, in Harvard Human Rights Journal, 16 (2003), pp. 27-39.

Rоoт, Elihu, The Declaration of the Rights and Duties of Nations Adopted by the American Institute of International Law, in The American Journal of International Law, 2/10 (1916), pp. 211-221 [available at: <http://www.jstor.org/stable/2187520> (last visited: 23 April 2018)].

ObregOn, Liliana, The Universal Declaration of Human Rights in Latin America, in Maryland Journal of International Law, 94/24 (2009), pp. 94-98 [available at: <http://digitalcommons.law.umaryland.edu/mjil/vol24/iss1/12> (last visited: 24 February 2018)]. 